\title{
Mirroring the Zeitgeist: An Analysis of CSR Policies in the UK's Food, Soft Drink and Packaging Industries
}

\section{Purpose}

The purpose of the article was to explore changes in CSR policies in food, soft drinks and packaging industries to capture changes in CSR implementation given increased environmental activism. The paper takes an exploratory approach in reviewing CSR policy changes to explore to what extent companies changes CSR policies with increased environmentalism.

\section{Design/methodology/approach}

A comparative website analysis was used to analyse CSR policies of companies in the food, soft drinks and packaging industries in the UK. The companies were selected for the analysis based on their annual turnover and a total of 23 companies was analysed (seven for the soft drinks industry, eight for the food industry and eight for packaging industry). Five interviews were conducted with packaging and retail professionals, and the findings were analysed using thematic analysis, which captured trends in responses.

\section{Findings}

The findings show that companies are implementing and communicating CSR policies heavily focused on reducing the environmental impact of their work and matching social debates on human rights, with which traditional CSR policies (corporate governance, supporting local communities and consultation with stakeholders) are fading away. Instead, companies have shifted attention towards the gender pay gap, modern slavery and extensive environmentalism. The interviews with packaging professionals and CSR managers from the retail industry show that the packaging industry designs CSR policies in line with requests from supermarkets, which are, in turn, influenced by consumer activism.

\section{Originality/value}

The paper provides an insight into CSR implementation of three industries that faced heavy criticism from campaigners and the general public for their environmental impact. The paper shows how the CSR policy shifted to match this expectation and thus provides a good ground for studying the evolution of CSR using a case study from three selected industries.

\section{Practical Implications}


The paper shows the circular relationship between media coverage, consumer activism that comes as a result and the impact and changes this brings to the industry. In order to avoid reputation damage, companies should closely follow media debates to pre-empty consumer criticism and activism.

\section{Social Implications}

The findings show that companies are 'mirroring the zeitgast' and going with trends to meet consumer expectations, which brings into question the sincerity of CSR policies and revives criticism of capitalism and raises a question whether CSR is used by companies as a smokescreen that on the outset makes a difference to the society but keeps status quo intact.

\section{Introduction}

Corporations are functioning in a world where they are encouraged to, and in many cases, expected to, behave in a socially responsible way across a range of issues, including environmental protection, engagement with stakeholders and workers' rights (Diers-Lawson et al, 2020; Freeman and Hasnaoui, 2011; Tench et al, 2014; Topić and Tench, 2018; Campbell, 2007; Yuan et al, 2011; Falkenberg and Brunsael, 2011; Morsing, 2008). Companies "are faced with greater demands for detailed information regarding the social and environmental impacts of their business activities" (Burchell and Cook, 2006: 154, 167), and are urged to communicate activities related to Corporate Social Responsibility (CSR) (Crane and Glozer, 2016; Jones et al, 2017; McWilliams and Siegel, 2001). All the while, critical journalists, consumer groups and Non-Governmental Organisations (NGOs) are pushing companies to give more to societies (Grafström and Windell, 2011; Johansen and Nielsen, 2011).

According to Campbell (2007), companies are more likely to act in socially responsible ways when state regulation is strong and when they are being monitored by independent organisations. However, the majority of companies engage in CSR to "enhance corporate reputation, pre-empt legal sanctions, respond to NGO actions or to manage risk and generate customer loyalty" (Yuan et al, 2011: 86, see also Falkenberg and Brunsael, 2011: 11). As a result, there has been "an increasing trend towards the integration of non-financial and financial information in corporate reports" (Zicari, 2014: 202). This also means that companies are now expected to report their performance and activities, and some are even obliged to do so depending on their registration and domestic legislation. 
In this paper, CSR policies across the soft drink, food and packaging industries were analysed. The soft drink and food industries were selected due to campaigning and criticism of these industries for their contribution towards obesity and undermining the health of the population whilst the packaging industry was selected due to its contribution towards climate change. Given that these industries are in the spotlight in regards to media and consumer criticism (Bridge et al, 2020; Bridge et al, 2020a; Topić and Tench, 2018; Elliott Green et al, 2016; Buhr \& Grafström, 2006; Tench et al, 2007; Ihlen, 2008; Grayson, 2009; Grafström \& Windell, 2011), the paper explores which CSR policies the industries are engaged with, whether there are differences between the CSR policies engaged by the industries and how CSR policies are changing given increased environmental and health activism. In addition, five interviews were conducted with packaging professionals and CSR and sustainability managers in two main supermarkets in the UK to further explore findings from the content analysis.

\section{CSR Trends}

Many organisations adopt socially responsible programmes expecting rewards from customers, but not all customers accept these initiatives in the same way. Instead, "when motivations are considered as firm serving or profit related, attitudes toward firms are likely to diminish; when motivations are considered socially motivated, attitudes towards firms are likely to be enhanced" (Becker-Olsen and Hill, 2005: 8). Some authors also claim that consumers will leave if CSR is enforced at the expense of quality (Morsing and Schultz, 2006; Boulstridge and Carrigan, 2000). It has also been stated that consumers do not base purchase decisions on CSR programmes (Mohr et al, 2001; Morsing et al, 2008). This is summarised in the following point:

"If they don't say enough about their charity links consumers believe that companies are hiding something and if they say too much they believe that charities are being exploited by the big corporations. It makes the promotion of such schemes one of the most delicate jobs in marketing. Go too far one way and consumers believe you are using the charity, go the other way and they will not even know of your involvement" (O’Sullivan, 1997, cited from Simcic Bronn \& Vrioni, 2001: 217).

In other words, because of the intensification of debates about CSR, some authors state that the more companies communicate their CSR, the more attention and criticism they gain (see e.g. Ashforth and Gibbs, 1990; Morsing et al, 2008). On the other hand, if companies are not communicating their CSR enough consumers can wonder if a company is hiding something (Brown and Dacin, 1997; Morsing et al, 2008). Research has also shown that consumers are 
only willing to reward companies for CSR if they trust in a company's social policies in general and not in particular initiatives (Yoon et al, 2006). Furthermore, perceptions of CSR activities are not the same for all companies, for instance, "CSR activities do not enhance the reputation of companies that are perceived to be unethical" (Strahilevitz, 2003, cited from Yoon et al, 2006: 378).

O'Connor and Meister (2008: 49) defined CSR as “...corporate engagement in socially responsible behaviors in response to societal demands, the desires of influential publics, and the ability of such activities to increase competitiveness and stock performance. Socially responsible behavior is synchronized with the economic, ethical, and moral expectations of society at a given point in time. CSR is largely voluntary and is considered closely linked to an organization's ability to maintain legitimacy." Other authors define CSR by using a variety of policies such as environmental concerns and interaction with stakeholders (Perrini, 2005) or "corporate responsibility, corporate citizenship, sustainability, and corporate social performance" (Freeman and Hasnoui, 2011: 419). However, CSR is more complex than just stating what it entails because how CSR is defined also depends on the political position of the author. For example, neo-classical economists supporting laissez-faire and open markets largely follow Friedman's (1970: 6) definition of business responsibility, which reads,

"There is one and only one social responsibility of business--to use its resources and engage in activities designed to increase its profits so long as it stays within the rules of the game, which is to say, engages in open and free competition without deception or fraud".

In this view, CSR is an attempt to impose public social preferences on private property (Krugman, 2007; Sheehy, 2014). On the other hand, centrist-left agenda is set to delivering more equal and just society and thus supports the introduction of CSR, with NGOs being the main actors in promoting this agenda (Sheehy, 2014). This group "sees private property and related commercial rights as rights secured by the government and views the large industrial organisation as a social institution which should be shaped to meet the needs of society" (ibid: 3). The far left-wing agenda equates CSR with neo-liberalism and as a smokescreen that prevents and limits changes in the society (Fleming and Jones, 2013; Ireland and Pillary, 2013; Sheehy, 2014). Therefore, the view on CSR largely depends on political views of authors, however, companies are nowadays implementing CSR policies and trying to show that they are doing something good for the society and expect to be seen positively by consumers 
(Einwiller et al, 2019). There is the widespread engagement of organisations in CSR activities, which highlights "the recognition that brand names depend not only on quality, price and uniqueness but on how, cumulatively, they interact with companies' workforce, community and environment" (Department of Trade and Industry, 2004, cited from Harrison, 2010, p. 192).

There has been an increasing interest in the business practices of food, soft drink and packaging industries due to their potential negative impact on human and environmental health. For example, soft drink and food industries faced scrutiny before the introduction of the sugar tax (Topić and Tench, 2018) whilst plastic usage by the packaging industry is heavily debated by policy and media stakeholders (see BBC' article thread on ocean pollution; BBC, 2020). The present study explores the CSR policies implemented by food, soft drink and packaging industries and seeks to assess whether policies on CSR are changing given increased environmentalism. The research questions for this study were,

RQ1. What CSR policies do food, soft drink and packaging industries in the UK implement?

RQ2. How do the CSR policies vary within and between food, soft drink and packaging industries?

RQ3: Is the nature of CSR changing?

\section{Method}

A sample of companies with the highest turnover from the UK food, soft drink and packaging industries were included in the analysis. Seven companies from the soft drink industry, eight from the food industry and eight from the packaging industry. All companies included in the analysis had a website, and each website was manually searched to identify company policies related to CSR. Sitemaps were used to locate policies. An inductive coding method was used for policy identification, whereby a list of policy types was recorded and added to until saturation was achieved and no new policies were identified. The presence or absence of CSR policies by policy type was recorded manually in an Excel spreadsheet (see Table 1 for a summary of the types of CSR policies communicated by the companies included in the analysis).

The CSR policies were assessed and compared via a method of comparative website content analysis. The method applied the principles of content analysis to systematically examine the content of CSR policies presented on the websites. This method has been widely employed in CSR research previously (Berelson, 1952; Gray et al, 1995). For example, Kuada and Hinson 
(2012) adopted a comparative approach to the study of CSR in Ghana where they analysed similarities between foreign and local companies whereas Hurst (2004) determined "how ethics and CSR practices of European-based companies compare to US-based companies" (2). Besides, Golob and Bartlett (2006) conducted a "comparative study of two countries in two different world regions" (2) whilst William and Aquilera (2008) argued that "comparative research is difficult to conduct, given the complexity of data collection" (459), which is what this paper addresses by focusing on three industries which have public scrutiny in common given the recent rise of environmentalism. By using this approach, this study contributes to the debate on CSR through the use of examples from food, soft drinks and packaging industries.

Whilst companies use several reporting methods to communicate their CSR activities including press releases, annual reports and newspaper advertisements, company websites represent a key communication method used by firms to disclose CSR activities and are a useful option for research as the information is freely accessible. Comparative website data analysis was considered as an appropriate method for the assessment of CSR policies as it seeks to compare "like" with "like" unobtrusively and objectively, allowing researchers to assess the artefact of interest (i.e. CSR policies) rather than an individual or company itself (Krippendorff, 1980). Moreover, as the data included in the assessment is freely accessible, the method could be replicated by other researchers across other industry areas.

Only publicly available data was used and the research obtained approval from the local research ethics coordinator. The data is presented in an aggregate form, as the aim of the research is not to measure the performance of each company but to explore which CSR policies are implemented in three selected industries (food, soft drinks and packaging).

As the findings below will show, the packaging industry was least active in CSR implementation of three analysed industries, which came as a surprise to researchers given the prominence of plastic in media and social media debates. Therefore, interviews were conducted with professionals in charge of CSR in the packaging industry. The original aim was to conduct around 10 interviews, however, it became clear after first three interviews were conducted that all members of the industry are saying one same thing, and thus saturation was reached unexpectedly early. However, since packaging professionals mentioned retailers as influencers of their CSR implementation, two interviews were conducted with sustainability and packaging managers in two major UK supermarkets who then again said the same thing and enabled an unexpectedly early saturation in responses. 
The interviews were done via telephone, given the coronavirus pandemic and the lockdown in the UK, and the findings were analysed using thematic analysis. Thematic analysis is a good method for exploratory research such as this study as it enabled identifying themes and trends in data. Thematic analysis is a sense-making method, which was convenient for this study where researchers wanted to make sense of changes in CSR implementation. In summary, thematic analysis is "a systematic approach to the analysis of qualitative data that involves identifying themes or patterns of cultural meaning; coding and classifying data, usually textual, according to themes; and interpreting the resulting thematic structures by seeking commonalities, relationships, overarching patterns, theoretical constructs, or explanatory principles" (Lapadat 2010, p. 926). In the presentation of findings of interview data, the approach introduced by Braun and Clarke (2006) where a thematic graph identifying trends has been created and the elaboration also uses a selection of statements from interviewees.

The findings below are, therefore, firstly elaborating on the website content analysis (23 websites) and then proceed with explaining those findings with data from five conducted interviews.

\section{Findings}

Fifteen categories of CSR implementation were identified from the information published on company websites (Table 1).

Table 1. Corporate Social Responsibility policies present on the websites of the companies included in the analysis

1. Climate change (reducing emissions)

2. Consultation with stakeholders

3. Corporate governance plan

4. Diversity in workforce/ investing in employees

5. Gender pay gap report

6. Health advice and policies to customers and/or employees

7. Modern slavery statement

8. Public reports on the implementation of the sustainability plan

9. Recyclable and compostable packaging

10. Reducing sugar/calories

11. Reducing the impact on water

12. Supporting local communities 


\section{Sustainability action plan in place}

14. Sustainable sourcing (supply chain management)

15. Waste management for packaging

However, when it comes to the use of CSR policies, it appears that the three most commonly used policies are waste management for packaging, used across industries, the use of recyclable packaging and tackling climate change (reducing emissions), with which companies working in these industries are responding to the global debate on the climate change and plastic pollution (Figure 1).

\section{Figure 1. CSR policy use across all industries}

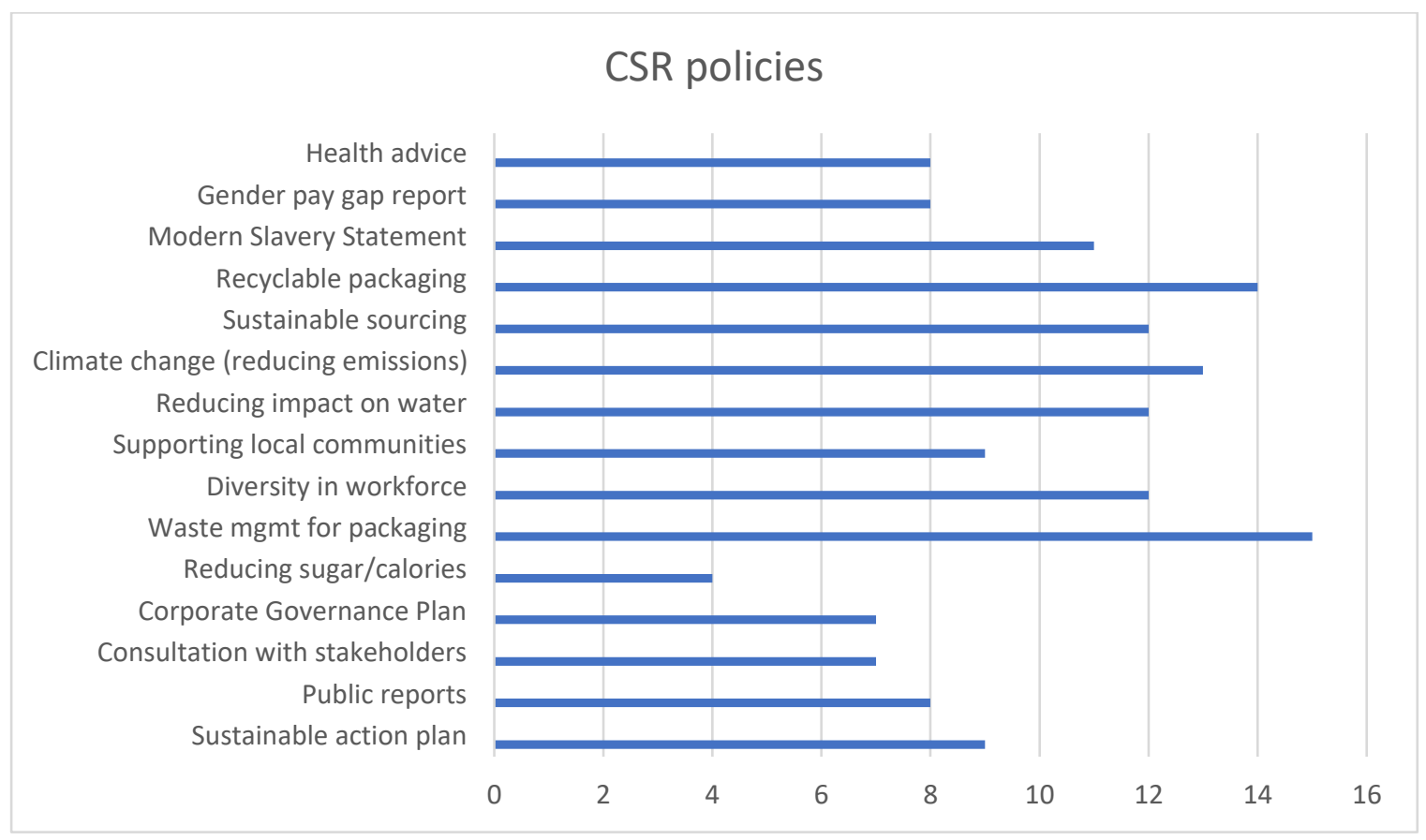

Some companies also went a step forward and implemented new policies such as the gender pay gap report $(n=8)$, modern slavery statement $(n=11)$ and offering health advice to consumers and employees $(n=8)$. The gender pay gap, modern slavery statement and health (e.g. the debate on obesity) are also issues that have been prominent in recent public debates (Bridge et al, 2020a; Topić and Tench, 2018; Elliott Green et al, 2016; Buhr \& Grafström, 2006; Tench et 
al, 2007; Ihlen, 2008; Grayson, 2009; Grafström \& Windell, 2011) and since these policies are prominent in companies' CSR, it appears as if companies are following public debates and concerns expressed by the media and the general public and trying to respond by communicating what they are doing to tackle these issues.

The number of CSR policies across the three industries and the average number of CSR policies per company are summarised in Table 2 .

Table 2. CSR policies present on the websites of the companies included in the three-industry sample

\begin{tabular}{|l|l|l|l|}
\hline Industry & $\begin{array}{l}\text { Soft } \\
\text { Drink }\end{array}$ & Packaging & Food \\
\hline $\begin{array}{l}\text { Count of total CSR policies across industry } \\
\text { sample }\end{array}$ & 46 & 40 & 63 \\
\hline $\begin{array}{l}\text { The average number of CSR policies described } \\
\text { per the company website }\end{array}$ & 6.6 & 5 & 7.9 \\
\hline
\end{tabular}

\section{Soft Drinks Industry}

Across all soft drink companies included in the sample, 46 CSR policies were identified across the websites, averaging 6.6 CSR policies per the company website. However, across the industry, the number of CSR policies documented ranged from two to 14. The most frequently reported CSR policy across the websites of the soft drink companies included in the sample was the modern slavery statement $(n=5)$. In contrast, the documentation of the corporate governance plan and a statement on sustainable sourcing were only present on one website each.

\section{Food industry}

Overall, the food industry had the most CSR policies described on the company websites $(n=63)$, with 7.9 CSR policies on each website. However, this ranged from $5-12$ policies across the companies included in the sample.

Across the food companies included in the sample, the most frequently reported CSR policies mentioned on six company websites were: waste management and recyclable and compostable packaging; diversity in the workforce / investing in employees; and supporting local 
communities. The least reported CSR policies across food companies, both reported on only two company websites, were: public reports on the implementation of the sustainability plan and reducing sugar and/or calories.

\section{The packaging industry}

The packaging companies had the lowest number of CSR policies documented on their websites with a total of 40 policies described across the eight companies included (an average of five policies per company). The most frequently reported CSR policies documented across the companies included were health advice and policies to customers and/or employees and supporting local communities. Only one company published a gender pay gap report on their website, whilst a corporate governance plan was published by one company.

It, therefore, seems that the CSR is changing to capture new policies. Whilst responding to the climate change could be seen as traditional CSR policy since CSR always had an environmental concern embedded into the concept (Perrini, 2005), gender pay gap, health concerns and modern slavery statements are new policies introduced after recent public debates. For example, the UK Home Office introduced a document tackling modern slavery in 2014 and the document is continually being updated (Home Office, 2020). This policy is of frequent interest to the media, with some advocates calling for further changes and toughening up of the Modern Slavery Act (e.g. Hodal, 2019; Abbit, 2020). Equally, the gender pay gap intensified in the past few years with campaigning from feminist activists, such as the Fawcett Society which launched a campaign 'Right to Know' advocating for closing the pay gap and disclosing the information (Fawcett Society, 2020) and academics from a variety of academic disciplines. The UK Parliament monitors the pay gap in industries and, in 2020, they published a briefing paper, outlining pay gap per industry (UK Parliament, 2020) whilst the UK Government has a tool allowing members of the public to compare gender pay gap for employers with 250 or more employees as well as full data on the gender pay gap in the UK (UK Government, 2020). Companies included in this study can be seen as responsive to public concerns and campaigning as they are implementing CSR policies tackling social issues as they arise.

After the completion of website analysis, and as already emphasised, five interviews were conducted. Three interviews were conducted with CSR managers from the packaging industry, and because of their responses two interviews were conducted with CSR and sustainability managers in two main supermarkets. The findings show a circular relationship of CSR implementation where the packaging industry implements requests from supermarkets, who 
are in turn influenced by consumer activism and BBC Blue Planet, the latter being the main perceived reason for consumer activism (Figure 2).

\section{Figure 2. The Circular CSR Relationship}

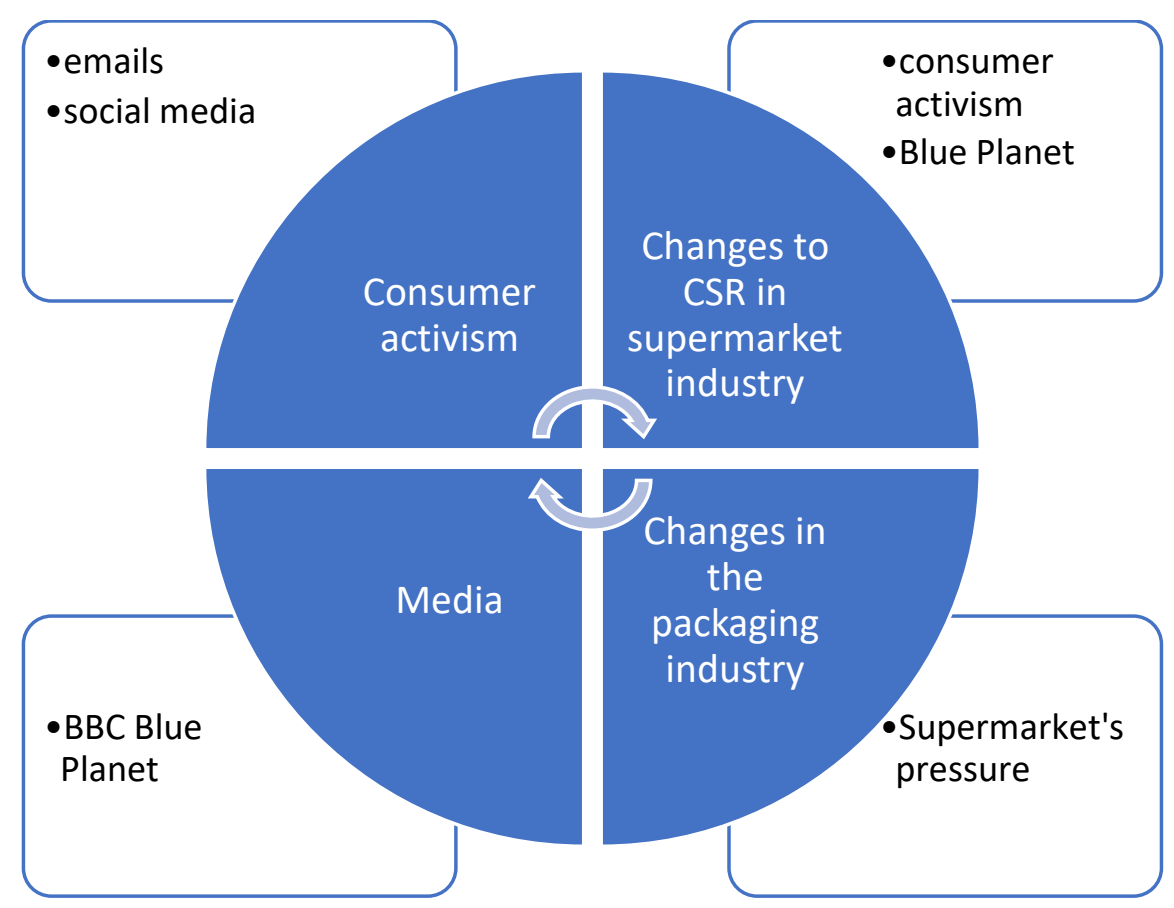

In other words, packaging professionals stated they do not have direct contact with consumers, and thus do not feel in the spotlight nor they face an immediate reputation threat as supermarkets do. This is because they are not allowed to put their company's name on labelling and thus there is no prospect for customers to dislike the packaging and contact them directly. Instead, consumers will approach supermarkets who will then contact the packaging company. The packaging industry, however, emphasised that the reason for increased consumer activism lies in BBC' Blue Planet series which influenced consumer activism and shifted it towards plastic. The interviewed professionals spoke of the 'Blue Planet Effect' and emphasised that because of environmental activism the market got "more fierce", this in large part is due to "massive jump in customer queries". However, all packaging professionals also emphasised that they regularly review CSR policies and were active in CSR even before the consumer activism and the pressure for supermarkets. Some, however, expressed disappointment with the BBC programme and consumer views that followed by emphasising that the emphasis 
should be on human behaviour that leads to pollution of oceans rather than companies producing packaging. One CSR manager, however, stated that companies only look for profit, including his company, and do what they absolutely have to in order to avoid criticism and reputation damage.

Supermarket professionals in charge of CSR and sustainability confirmed the above and argued that they are seeing an increased pressure of both media and consumers in regards to environmental protection. One supermarket manager said, for example, that they went from hundreds of emails per year from consumers in regards to environmental protection to more than 6000 and this was echoed by another supermarket that also had an increase in customer enquiries. Supermarkets, however, emphasise that they are trying to "meet customer expectations" and do "what people want", thus confirming the view of packaging professionals that they are a) influenced by consumers and b) that they are doing what they have to in regards to CSR albeit they do say they are committed to CSR and think consumers are rightfully concerned.

Supermarkets do not report direct media influence, such as for example negative coverage, but they report media influencing consumers who then turn to social media to influence them, thus showing that consumers have the major power when it comes CSR implementation, however, this activism largely comes from the media.

\section{Discussion}

This study aimed to assess the CSR policies implemented by a sample of companies with high turnover across the food, soft drink, and packaging industries in the UK, to explore which CSR policies exist and how they vary between industries. Content analysis of the CSR policies implemented, based on website information, revealed that the companies in the food and soft drinks industry had a more developed CSR strategy than companies working in the packaging industry, with more CSR policies published across the food and soft drink company websites.

This finding could be explained by the increased media activism that has been centred on reducing sugar intake and obesity in the UK. This has placed heavy pressure on food and soft drinks companies to make changes to improve the nutrition content of their products for health (Topić and Tench, 2018). In addition to this pressure to improve the nutrition content of food and drink products, there has been widespread discussion in the media relating to plastic in oceans, largely following the broadcasting of the BBC's documentary, Blue Planet (Gell, 2019). Much of the media coverage has been focussed on individual behaviour change and the 
potential actions of the food and soft drink industry to elicit change (Bridge et al, 2020; Bridge et al, 2020a; Topić and Tench, 2018; Elliott Green et al, 2016). In reaction to this media attention, food and drink companies published CSR reports on their actions to become more sustainable including the work they are doing to recycle packaging or reduce water usage.

Even though there was an overall greater number of CSR policies on the websites of the food and drink industry, the policies present varied between the two industries and the companies in each industry. The food industry was most active in its CSR, which supports previous research exploring CSR by the industry (Jones et al., 2008). In addition to acting as a communication channel, as suggested by Jones et al. (2008) the high publication of CSR policies on food company websites may also reflect the industry's impact and dependence on the economy, the environment and on society. Together this may lead to the industry having to be conscious of, and report on the production of raw materials (animal welfare), the environmental (e.g. energy, water use and waste) and social (labour conditions) across the food whole value chain in the form of CSR reports (Maloni and Brown, 2006).

When it comes to the packaging industry, interview data clarified that the packaging industry is influenced by the supermarkets who are influenced by consumers. Therefore, the findings show a dual relationship in regards to media influence. From one point, the BBC made a programme that influenced consumers who, in turn, took to social media and emails to influence supermarkets. The latter then, as already emphasised, influenced the packaging industry. It comes as no surprise that consumers took the programme promoted by BBC seriously as $\mathrm{BBC}$ is continually rated as the most trusted media in the UK albeit there is a general decline in trust in the media (Silver, 2019; YouGov, 2019).

\section{Conclusion}

Presented in this paper are the results of a study of CSR implementation in the UK through an examination of the websites of soft drink, food and packaging industries operating in the UK context. The findings highlight that, of the three industries, the packaging industry was least active in its implementation of CSR policies, whilst the food industry was most active. These findings could be explained in part by the importance of food safety, but also by the increased media attention and societal pressure on the food industry to reduce sugar content and act in a more environmentally friendly way (Bridge et al, 2020; Bridge et al, 2020a; Topić and Tench, 2018; Elliott Green et al, 2016; Buhr \& Grafström, 2006; Tench et al, 2007; Ihlen, 2008; Grayson, 2009; Grafström \& Windell, 2011). In addition to that, interviews revealed that the 
packaging industry works under the guidance of the supermarkets, who are influenced by consumers. It is not clear where the influence on consumers is coming from. For example, it remains open whether consumers watched Blue Planet programme, which is cited by both packaging and retail industries as the reason for increased environmental activism among consumers. Alternatively, the consumers could have read about the Blue Planet programme, or other environmentally focussed pieces, in the press, which traditionally sets the agenda (McCombs, 2014; Topić, 2020). Future research could analyse the press coverage of the Blue Planet series and then conduct a public survey to explore who or what influenced consumer activism. Even if consumers were influenced by the press writing about the programme, which would be in line with all media research in the field, it is still novel for a TV programme to instigate a major debate in the press and then achieve such a profound influence on consumers, and through a snowball effect, impact industry policies. This requires further research to explore to what extent $\mathrm{BBC}$ as a public broadcaster sets the agenda in the $\mathrm{UK}$, and with which the UK might prove to be an entirely different and unconventional media system should a more detailed analysis proves a long-term agenda-setting influence of BBC.

What also emerges from this analysis is that many companies are responding to societal trends and implementing and communicating CSR, which matches social debates and expectations. This particularly applies to the food industry, which was a subject of criticism of campaigners and the media (Topić and Tench, 2018). However, it also seems that the shift towards widening environmental policies means that the traditional stakeholder elements of CSR are fading away as new policies take place. In other words, corporate reporting and communication with stakeholders are less present than one would expect given the vast amount of literature on stakeholder approach of CSR (see e.g. Freeman, 2010; Tench et al, 2014). Thus, policies such as climate change, gender pay gap, packaging, waste management and modern slavery have gained prominence. Since modern slavery and gender pay gap reports are policies largely driven by campaigners such as NGOs and then promoted by the Government and Parliament, it seems that the corporate world is following Government's action and thus responding to changes in the legal system and policy expectations (Sheehy, 2014) as well as customer expectations. This brings back Friedman's argument (1970) that companies are responsible for shareholders and making a profit while abiding by laws and 'rules of the game'. It seems that this might be the trend in CSR implementation in the UK where analysed companies follow changes in policy and public views and react appropriately whilst dropping attention from other elements that used to be a hot topic of the stakeholder approach to CSR, such as corporate 
governance plan, consultation with stakeholders or supporting local communities. In other words, O'Connor and Meister (2008) defined CSR as a corporate behaviour that reacts to social demands and the wishes of influential publics to increase competitiveness and performance in the stock market. This description seems to be fitting for UK companies in the food, soft drinks and packaging industries, which seem to follow social trends often pushed on the public agenda by influential publics, such as NGOs and the Government (Sheehy, 2014) and thus communicate policies that match social expectations only (Fleming and Jones, 2013; Ireland and Pillary, 2013; Sheehy, 2014).

\section{Limitations}

Whilst websites are an important platform for the publication of CSR reports, communication of CSR is unlikely to be solely through the mechanism of the company website. It is possible that other communication methods are used, such as social media and annual reports and as these materials were not specifically studied in the study, the conclusions drawn here are limited. Future research could consider the differences, if any, between the different media used in the communication of CSR by companies or industry groups.

Although companies with the largest turnover across the food, soft drink and packaging industries in the UK were included in the study, the findings may not be generalisable to smaller companies within these industries since they may take alternative approaches to CSR implementation. Future research could assess the implementation of CSR across a larger number of companies, or between more industries, to assess similarities or differences between industry groups.

\section{References}

Abbit, B. (2020), “No job, no bank account, no money - a woman's fight to rebuild her life after escaping sex slavery", Manchester Evening News, 29 March, retrieved from https://www.manchestereveningnews.co.uk/news/greater-manchester-news/no-job-no-bankaccount-17931094 (accessed 30 March 2020)

Ashforth, B. E. and Gibbs, B. W. (1990), "The double-edge of organizational legitimation”, Organization Science Vol 1 No 2, pp. 177-194.

BBC (2020), “Ocean Pollution”, retrieved from https://www.bbc.co.uk/news/topics/cnegp3jvj32t/ocean-pollution (accessed 30 March 2020). Becker-Olsen, K. L and Hill, R. (2005), "The Impact of Perceived Corporate Social 
Responsibility on Consumer Behavior. Center for Responsible Business", Working Paper Series, 2-30, retrieved from http://escholarship.org/uc/item/98f4n4fr (accessed 8 April 2015).

Berelson, B. B. (1952), “Content Analysis in Communication Research”, Free Press, New York.

Boulstridge, E. and Carrigan, M. (2000), "Do consumers really care about corporate responsibility? Highlighting the attitude—-behaviour gap", Journal of Communication Management Vol 4 No 4, pp. 355 - 368.

Braun. V., \& Clarke, V. (2006), "Using thematic analysis in psychology”, Qualitative Research in Psychology, 3(2), 77-101.

Bridge, G., Tench, R. and Flint, S. (2020), "Influencing the influencers: talking about sugar taxes on Twitter -who's controlling the debate?", Influence in the development and implementation of the UK Soft Drink Industry Levy project, retrieved from https://www.researchgate.net/publication/338571392_Influencing the_influencers_talking_a bout_sugar_taxes_on_Twitter_-who's_controlling_the_debate (accessed 30 March 2020)

Bridge, G., Lomazzi, M. and Bedi, R. (2020a), "Implementation of a sugar-sweetened beverage tax in low-and middle-income countries: Recommendations for policymakers", Journal of Public Health Policy Vol 41, pp. 84-97.

Brown, T. J. and Dacin, P. A. (1997), "The Company and the Product: Corporate Associations and Consumer Product Responses", Journal of Marketing Vol 61, pp. 68-84.

Burchell, J. and Cook, J. (2006), "It's good to talk? Examining attitudes towards corporate social responsibility dialogue and engagement processes", Business Ethics: A European Review Vol 15 No 2, pp. 154-170.

Buhr, H. and Grafström, M. (2006), “The Making in the Media: The Case of Corporate Social Responsibility in the 'Financial Times', 1988-2003”, retrieved from http://www.fek.uu.se/gems/publications/Buhr_Grafstrom_CSR_2006.pdf (accessed 26 March 2015)

Campbell, J. L. (2007), "Why would corporations behave in socially responsible ways? An institutional theory of corporate social responsibility", Academy of Management Review Vol 32 No 3, pp. 946-967. 
Capriotti, P. and Moreno, A. (2007), "Corporate citizenship and public relations: The importance and interactivity of social responsibility issues on corporate websites", Public Relations Review Vol 33, pp. 84-91.

Crane, A. and Glozer, S. (2016), "Researching Corporate Social Responsibility Communication: Themes, Opportunities and Challenges”, Journal of Management Studies Vol 53 No 7, pp. 1223-1252.

Diers-Lawson, A., Coope, K. and Tench, R. (2020), "Why can CSR seem like putting lipstick on a pig? Evaluating CSR authenticity by comparing practitioner and consumer perspectives", Journal of Global Responsibility, EarlyCite, retrieved from https://www.emerald.com/insight/content/doi/10.1108/JGR-02-2020-0033/full/html

Einwiller, S., Lis, B., Ruppel, C. and Sen. S. (2019), "When CSR-based identification backfires: Testing the effects of CSR-related negative publicity", Journal of Business Research Vol 104, pp. 1-13.

Elliott-Green, A., Hyseni, L., Lloyd-Williams, F., Bromley, H. and Capewell, S. (2016), "Sugar-sweetened beverages coverage in the British media: an analysis of public health advocacy versus pro-industry messaging", BMJ Open Vol 6 No 7, retrieved from https://bmjopen.bmj.com/content/6/7/e011295 (accessed 30 March 2020)

Falkenberg, J. and Brunsæl, P. (2011), “Corporate Social Responsibility: A Strategic Advantage or a Strategic Necessity?”, Journal of Business Ethics Vol 99, pp. 9-16.

Fawcett Society (2020), "Right to Know", retrieved from https://www.fawcettsociety.org.uk/right-to-know

Fleming, P. and Jones, M. T. (2013), The end of corporate social responsibility: Crisis and critique, London, SAGE Publications.

Freeman, I. and Hasnaoui, A. (2011), "The Meaning of Corporate Social Responsibility: The Vision of Four Nations”, Journal of Business Ethics Vol 100 No 3, pp. 419-443.

Freeman, R. E. (2010), Strategic Management: A Stakeholder Approach, Cambridge, Cambridge University Press. 
Friedman, M. (1970), "The social responsibility of business is to increase its profits", New York Times Magazine, 32-33, pp. 122-126, retrieved from http://umich.edu/ thecore/doc/Friedman.pdf (accessed 30 March 2020)

Friedman M (1985), “Consumer Boycotts in the United States, 1970-1980: Contemporary Events in Historical Perspective", Journal of Consumer Affairs Vol 19 No 1, pp. 96-117.

Gell, F. (2019), "The Blue Planet effect: the plastics revolution is just the start", The Guardian, 25 March, retrieved from https://www.theguardian.com/commentisfree/2019/mar/25/plastics-revolution-marine-life (Accessed 6 April 2020)

Golob, U. and Bartlett, J. (2006), “Communicating about corporate social responsibility: A comparative study of CSR reporting in Australia and Slovenia”, Public Relations Review Vol 33, No 1, pp. 1-9.

Grafström, M. and Windell, K. (2011), “The Role of Infomediaries: CSR in the Business Press During 2000-2009”, Journal of Business Ethics Vol 103 No 2, pp. 221-237.

Gray, R., Kouchy, R. and Lavers, S. (1995), "Methodological themes: Constructing a research database of social and environmental reporting by UK companies", Accounting, Auditing and Accountability Journal, Vol 8 No, pp. 78-101.

Grayson, D. (2009), "Corporate responsibility and the media”, Doughty Centre Corporate Responsibility, retrieved from fromhttp://www.som.cranfield.ac.uk/som/dinamiccontent/research/doughty/crandthemediafinal.pdf (accessed 26 March 2015)

Gulyás, Á. (2009), “Corporate social responsibility in the British media industries preliminary findings", Media, Culture \& Society, Vol 31 No 4, pp. 657-668.

Harrison, A. (2010), Business Environment in a global context, Oxford, Oxford University Press.

Hodal, K. (2019), “One in 200 people is a slave. Why?”, The Guardian, 25 February, retrieved from https://www.theguardian.com/news/2019/feb/25/modern-slavery-traffickingpersons-one-in-200 (accessed 30 March 2020)

Home Office (2020), “Collection Modern Slavery”, retrieved from https://www.gov.uk/government/collections/modern-slavery (accessed 30 March 2020) 
Hurst, N. E. (2004), “Corporate ethics, governance and social responsibility: Comparing European business practices to those in the United States", A Study Conducted for the Business and Organizational Ethics Partnership Markkula Center for Applied Ethics Santa Clara University, Spring.

Idowu, S. and Towler, B. (2004), “A comparative study of the contents of corporate social responsibility reports of UK companies", Management of Environmental Quality, Vol. 15 No 4, pp. 420-437.

Ihlen, Ǿ. (2008), "Mapping the environment for corporate social responsibility”, Corporate Communications: An International Journal Vol 13 No 2, pp. 135-146.

Ireland, P. and Pillay, R. (2009). "Corporate social responsibility in a Neoliberal age", in P. Utting and J. C. Marques (Eds.), Corporate social responsibility and regulatory governance: Towards inclusive development? (pp. 77-104), New York, Palgrave-Macmillan.

Johansen, T. and Nielsen, A. (2011), "Strategic stakeholder dialogues: a discursive perspective on relationship building", in - M. Goodman, M. (ed.), Corporate Communications: An International Journal Vol 16 No 3, pp. 204-217.

Jones, D.A., Willness, C.R. and Glavas, A. (2017), "When Corporate Social Responsibility (CSR) Meets Organizational Psychology: New Frontiers in Micro-CSR Research, and Fulfilling a Quid Pro Quo through Multilevel Insights”, Frontiers in Psychology 8.

Jones, P., Comfort, D. and Hillier, D. (2008), “Corporate Social Responsibility and Marketing Communications Within Stores: A Case Study of U.K. Food Retailers”, Journal of Food Products Marketing Vol 14 No 4, pp. 109-119.

Krippendorff, K. (1980), Content analysis: An Introduction to its Methodology, Sage Publications, London.

Krugman, P. (2007), “Who was Milton Friedman?”, New York Review of Books, Vol 54 No 2, pp. 340-342.

Kuada, J. and Hinson, R.E. (2012), "Corporate social responsibility (CSR) practices of foreign and local companies in Ghana", Thunderbird International Business Review Vol 54 No 4, pp. 521-536. 
Lapadat, J. (2010), “Thematic analysis”, in Mills, A. J., Durepos, G. and Wiebe, E. (eds), Encyclopedia of case study research, Thousand Oaks: Sage (pp. 926-928).

Maloni, M. J. and Brown, M. E. (2006), "Corporate Social Responsibility in the Supply Chain: An Application in the Food Industry", Journal of Business Ethics Vol 68 No 1, pp. 35-52.

McCombs, M. (2014), "Setting the Agenda: The Mass Media and Public Opinion" (2nd edition), Cambridge, Polity.

McWilliams, A. and Siegel, D. (2001), "Corporate Social Responsibility: a Theory of the Firm Perspective", Academy of Management Review Vol 26 No 1, pp. 117-127.

Mohr, L. A., Webb, D.J. and Harris, K. E. (2001), “Do Consumers Expect Companies to be Socially Responsible? The Impact of Corporate Social Responsibility on Buying Behavior", Journal of Consumer Affairs Vol 35 No 1, pp. 45-72.

Morsing, M.; Schultz, M. and Nielsen, U. (2008), “The „Catch 22“of communicating CSR: Findings from a Danish Study”, Journal of Marketing Communications Vol 14 No 2, pp. 97-111.

Morsing, M. (2006), "Corporate social responsibility as strategic autocommunication: on the role of external stakeholders for member identification", Business Ethics: A European Review Vol 15 No 2, pp. 171-182.

O’Connor, A. and Meister, M. (2008), “Corporate social responsibility attribute rankings", Public Relations Review Vol 34, pp. 49-50.

Perrini, F. (2005), “Building a European Portrait of Corporate Social Responsibility Reporting”, European Management Journal Vol 23 No 6, pp. 611-627.

Robertson, D. C. and Nicholson, N. (1996), "Expressions of corporate social responsibility in U.K. firms", Journal of Business Ethics, Vol 15, pp. 1095-1106.

Schaltegger, S., Muller, K. and Hindrichsen, H. (1996), Corporate Environmental Accounting, John Wiley \& Sons, Chichester.

Silver, L. (2019), "How much does the UK public trust the media?", retrieved from https://www.bond.org.uk/news/2019/05/how-much-does-the-uk-public-trust-the-media 
Simcic Bronn, P. and Vrioni, A. B. (2001), "Corporate social responsibility and cause-related marketing: an overview", International Journal of Advertising Vol 20, pp. 207222.

Sheehy, B. (2014), "Defining CSR: Problems and Solutions", Journal of Business Ethics Vol 131, pp. 625-648.

Tench, R., Bowd, R. and Jones, B. (2007), "Perceptions and perspectives: corporate social responsibility and the media", Journal of Science Communication Vol 11 No 4, pp. $348-369$.

Tench, R., William, S. and Jones, B. (2014), "Introduction: CSR Communication as an emerging field of study", in Communicating Corporate Social Responsibility, Emerald Group Publishing Limited. Retrieved from https://books.emeraldinsight.com/page/detail/Communicating-Corporate-Social-

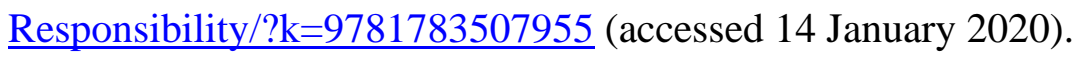

Topić, M. (2020), “The Sourcing of Stories on Sugar and the Supermarket Industry in the British Press", The Qualitative Report Vol 25 No 5, pp. 1196-1214, retrieved from https://nsuworks.nova.edu/tqr/vol25/iss5/3

Topić, M. and Tench, R. (2018), "Evolving Responsibility or Revolving Bias? The Role of the Media in the Anti-Sugar Debate in the UK Press", Social Sciences Vol 7 No 10, pp. 1-16.

UK Government (2020), “Gender pay gap service”, retrieved from https://gender-paygap.service.gov.uk/ (accessed 30 March 2020)

UK Parliament (2020), “The Gender Pay Gap”, Briefing paper, Number 7068, 6 March 2020, retrieved from file:///C:/Users/Home/Downloads/SN07068.pdf

Zicari, A. (2014), "Can one report be reached? The challenging of integrating different perspectives on corporate performance", in Tench, R.; Sun, W. and Jones, B. (eds.) Communicating Corporate Social Responsibility: Perspectives and Practice, Howard House: Emerald Books.

Williams, C. and Aguilera, R. V. (2008), "Corporate social responsibility in a comparative perspective” (pp. 452-472), in Crane, A., Matten, D., McWilliams, A., Moon, J. 
and D. S. Siegel (Eds.), Oxford Handbook of Corporate Social Responsibility, Oxford, Oxford University Press.

Yuan, W., Bao, Y. and Verbeke, A. (2011), "Integrating CSR Initiatives in Business: An Organizing Framework", Journal of Business Ethics Vol 101, pp. 75-92.

Yoon, Y., Gurhan-Canli, Z. and Schwartz, N. (2006), “The Effect of Corporate Social Responsibility (CSR) Activities on Companies With Bad Reputations”, Journal of Consumer Psychology Vol 16 No 4, pp. 377-390.

YouGov (2019). “Do Britons trust the press?” Retrieved from https://yougov.co.uk/topics/politics/articles-reports/2019/12/16/do-britons-trust-press 